\title{
Study on the Non-Compliant Landfill from Bârlad in Vaslui County
}

\author{
Biali Gabriela, Schneider Petra
}

\begin{abstract}
This paper presents a part of a comprehensive study on non-compliant landfill in Vaslui County. We have been tracking the subsidences taking place in the body of waste dumps and the amount of gas removed to take the best post-closure monitoring measures. In order to trace the behavior regarding the subsidence in the landfill body, there were placed in the ground 11 milestones/topographic landmarks of plastics, painted in white and red to be easily identified visually. Keeping them on the same positions made possible the analysis in the present study. Topographic surveys in the ground were performed once a month between April 2014 and September 2015. The results, interpretations and proposed solutions are presented in this paper.
\end{abstract}

Keywords - landfill, modeling, settling.

\section{INTRODUCTION}

The analysis of the issue of landfill compaction has aroused numerous reactions over the last thirty years. Therefore, one should not be in the least surprised of the impressive number of laws and applications found in literature, which are rather aimed at modeling landfill compaction than at controlling this phenomenon.

In order to facilitate their comparison with the observance of numerous criteria, it is important to show the findings of the research conducted, based on a particular type of chart. It includes four parts (assumptions, model, parameters and assessment) and it allows better determination of the advantages and disadvantages of each model.

\section{EXPERIMENT DESCRIPTION}

\subsection{Methodology for research}

The estimation of subsidences or slips in the bodies of landfills can be performed by using several methods. The mechanisms responsible for subsidence in landfills are more numerous and more complex than the one of soils. The structure of a massive amount of waste is fundamentally altered over time because of the amount of biodegradable organic matter and the present impressive volume of vacuum [1].

Manassero (1996) [1] divides the evolution of waste subsidence into 5 stages:

- mechanical compression associated with deformation, distortion, flexion, reorientation and crushing of elements (duration: several minutes); 
- reorganization accompanied by a reduction in volume due to the migration of small elements in the voids found among the larger elements (duration: 3 to 5 hours);

- consolidation and creep (duration: from 2-3 months to 1 year);

- subsidence caused by decomposition of organic matter (duration: from 10 to 50 years);

- decomposition of certain inorganic compounds due to corrosion and chemical reactions.

In the presented research, the model based on measurements made in the original place was used. All laws on the modelling of the subsidences of waste based on soil mechanics depend on a large number of parameters, whose determination is not at all easy even for soils. Applicable to waste, this parameter determination actually becomes a hazard taking into account the composition of the waste mass taken into consideration, the complexity of the biodegradation process that fundamentally alters its structure and composition over time, as well as the size of the constituent elements. The basis for effective joint work in the integrated vertical chain is trust. Effective connections between all participants combined with effective management of all units of the vertical chain with other good practices of customer relationship management ensures greater competitiveness on the market and allows creating a high quality, differentiated product with specific features desired by customers, as well as a reduction in production costs and the price.

\subsection{Description of the research site}

The Bârlad Landfill will be closed in the context of the ISPA program for Vaslui County. The landfill is situated in Romania, in Vaslui County. The Barlad landfill has an area of 6.41 ha and contains over 750 million $\mathrm{m}^{3}$ of waste. It is located in the outskirts of Bârlad town, in the eastern part of Bârlad town, in the administrative area of Zorleni commune, in the north-eastern part of the town, on the left bank of the river Bârlad. The landfill site is situated at a distance of approx. $300 \mathrm{~m}$ from the residential area of Bârlad. The storage started in 1979 and ended in 2006. The maximum thickness of the deposited waste layer is $7 \mathrm{~m}$. The current state of slopes and plateau does not allow qualified installation of a sealing surface that complies with Romanian legislation [2] and Romanian standards [2] without first leveling the landfill. The landfill is partially covered with soil and plants. Its slopes are very steep and irregular [3].

According to the requirements of the Treaty of Accession to the European Union, the landfill should have been closed by the end of 2007. The maximum thickness of the waste layer amounts to approximately $7.0 \mathrm{~m}$. The landfill does not have any collecting systems for leachate, landfill gas and water surface area [3].

The main shortcomings of the Bârlad landfill are as follows:

- its capacity is exceeded, there is a strong negative environmental impact on air, water surface and groundwater;

- no selective collection and recycling of landfilled materials from municipal waste is carried out;

- the site does not comply with the effective law.

Since 1969 storage in the landfill area has been performed from the entrance area on the east side of the landfill towards the eastern side. Thus, the previous storage area is situated in the western part of the landfill and the new one is located in the western part (Fig. 2). The non-compliant landfills Bârlad, Huşi, Negreşti from Vaslui County fall into the category of large non-hazardous waste landfills - Category b.3.

For tracing the behavior, there were placed milestones/topographical landmarks made of plastic, painted in white and red to be easily identified visually. Keeping them on the same positions made the analysis possible in this study. 
The layout of the topographic landmarks (milestones) on the body of the Bârlad landfill is presented in the following table and is shown in Fig. 1 of this study.

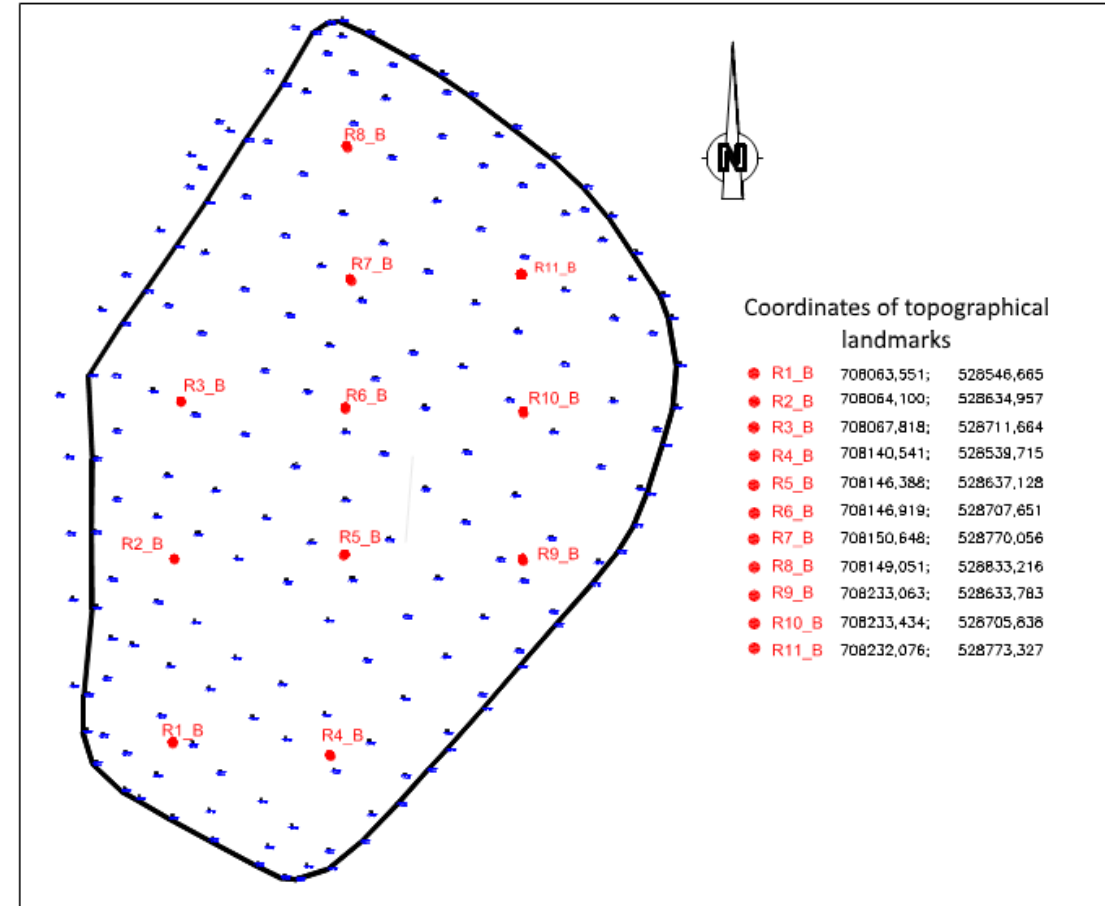

Fig. 1. Placement of the 11 topographical landmarks for measurement on the Bârlad landfill

\section{RESULTS AND SIGNIFICANCES}

\subsection{Topographical surveys}

Topographical surveys on the ground (Fig.3) were performed once a month between April 2014 and September 2015. Partial results (3 landmarks only) are shown in the following tables (Table 1-3).

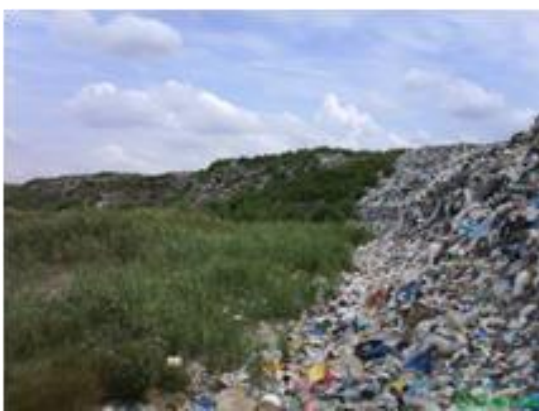

Fig. 2. The new storage area for the former Bârlad landfill

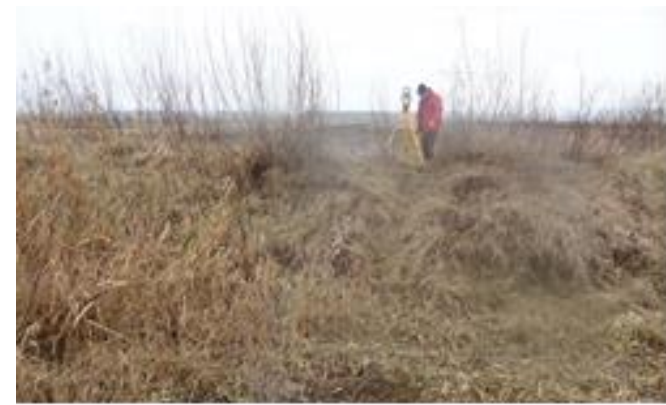

Fig. 3. Topographical surveys on the ground on the Bârlad landfill 
sciendo $_{20}$ Ovidius University Annals Series: Civil Engineering, Year 21, 2019

Table. 1. Readings on the topographical landmark R1_B on the Bârlad landfill

\begin{tabular}{|c|c|c|}
\hline Signal name & \multicolumn{2}{|c|}{$\mathbf{9 0 . 0 0 ~} \mathbf{~ m 1 \_ B}$} \\
& (reference Z) \\
\hline Date & Signal reading & Differences (cm) \\
\hline April 2014 & 78.96 & 11.04 \\
\hline May 2014 & 78.32 & 11.68 \\
\hline June 2014 & 77.02 & 12.98 \\
\hline July 2014 & 74.79 & 15.21 \\
\hline August 2014 & 73.02 & 16.98 \\
\hline September 2014 & 73.98 & 16.02 \\
\hline October 2014 & 75.63 & 14.37 \\
\hline November 2014 & 76.5 & 13.5 \\
\hline December 2014 & 83.53 & 6.47 \\
\hline January 2015 & 83.62 & 6.38 \\
\hline February 2015 & 82.78 & 7.22 \\
\hline March 2015 & 80.35 & 9.65 \\
\hline April 2015 & 82.74 & 7.26 \\
\hline May 2015 & 86.79 & 3.21 \\
\hline June 2015 & 88.14 & 1.86 \\
\hline July 2015 & 88.27 & 1.73 \\
\hline August 2015 & 88.36 & 1.64 \\
\hline September 2015 & 88.43 & 1.57 \\
\hline & & \\
\hline
\end{tabular}

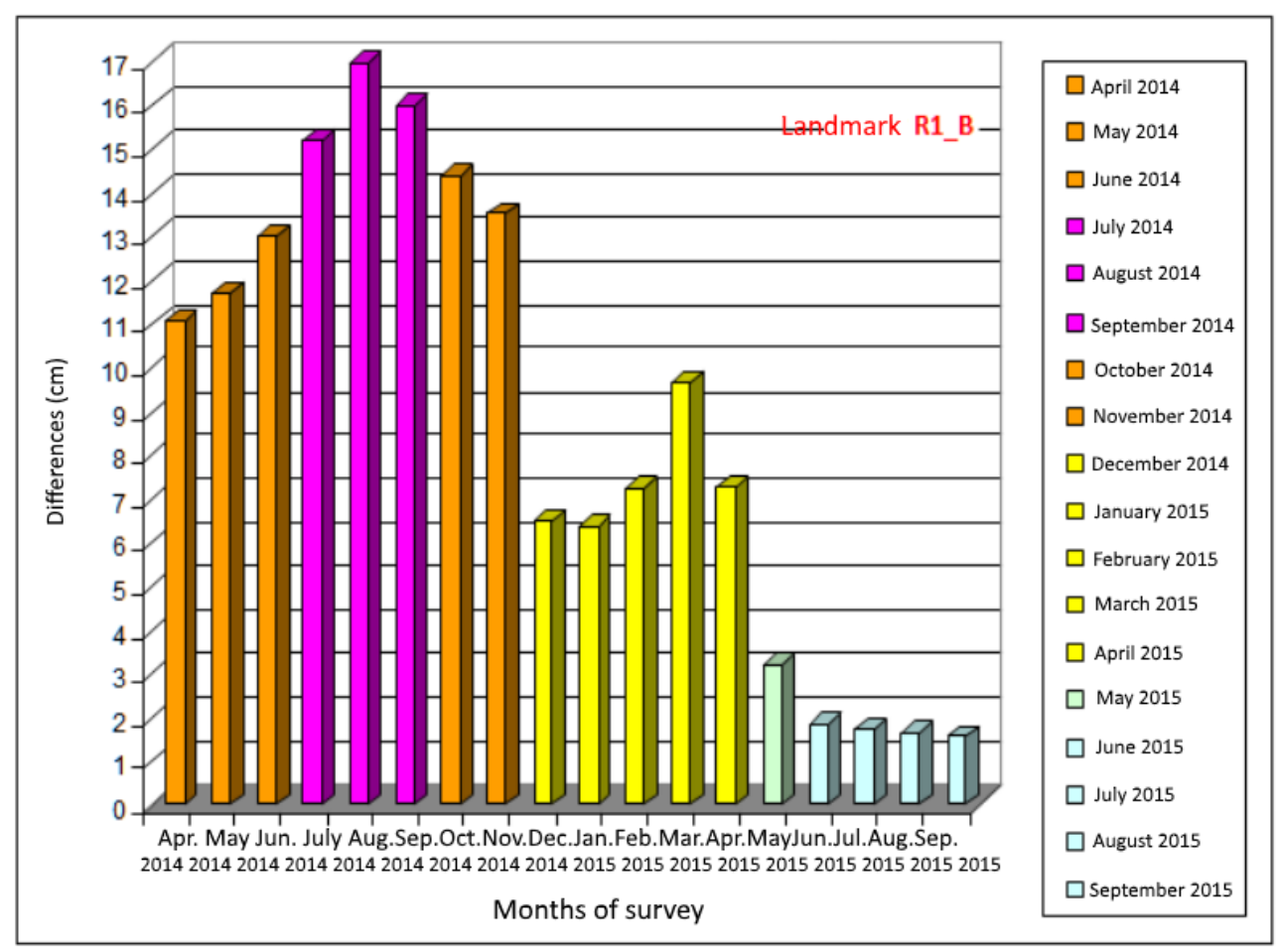

Fig. 4. Evolution of the subsidences on the body of the Bârlad landfill - Landmark R1_B 


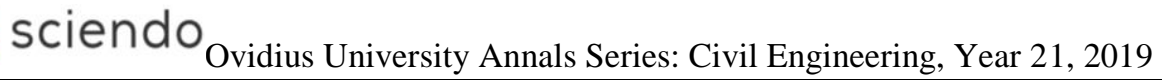

Table 2. Readings on the topographical landmark R4_B on the Bârlad landfill site

\begin{tabular}{|c|c|c|}
\hline Signal name & 90.00 & rence Z) \\
\hline Date & Signal reading & Differences $(\mathrm{cm})$ \\
\hline April 2014 & 77.46 & 12.54 \\
\hline May 2014 & 76.78 & 13.22 \\
\hline June 2014 & 71.31 & 18.69 \\
\hline $\begin{array}{l}\text { July } 2014 \\
\end{array}$ & 72.79 & 17.21 \\
\hline August 2014 & 72.02 & 17.98 \\
\hline September 2014 & 73.42 & 16.58 \\
\hline October 2014 & 74.31 & 15.69 \\
\hline November 2014 & 75.75 & 14.25 \\
\hline December 2014 & 77.11 & 12.89 \\
\hline January 2015 & 80.44 & 9.56 \\
\hline February 2015 & 83.79 & 6.21 \\
\hline March 2015 & 83.17 & 6.83 \\
\hline April 2015 & 82.88 & 7.12 \\
\hline May 2015 & 85.13 & 4.87 \\
\hline June 2015 & 86.05 & 3.95 \\
\hline $\begin{array}{l}\text { July } 2015 \\
\end{array}$ & 86.29 & 3.71 \\
\hline August 2015 & 87.62 & 2.38 \\
\hline September 2015 & 87.89 & 2.11 \\
\hline
\end{tabular}

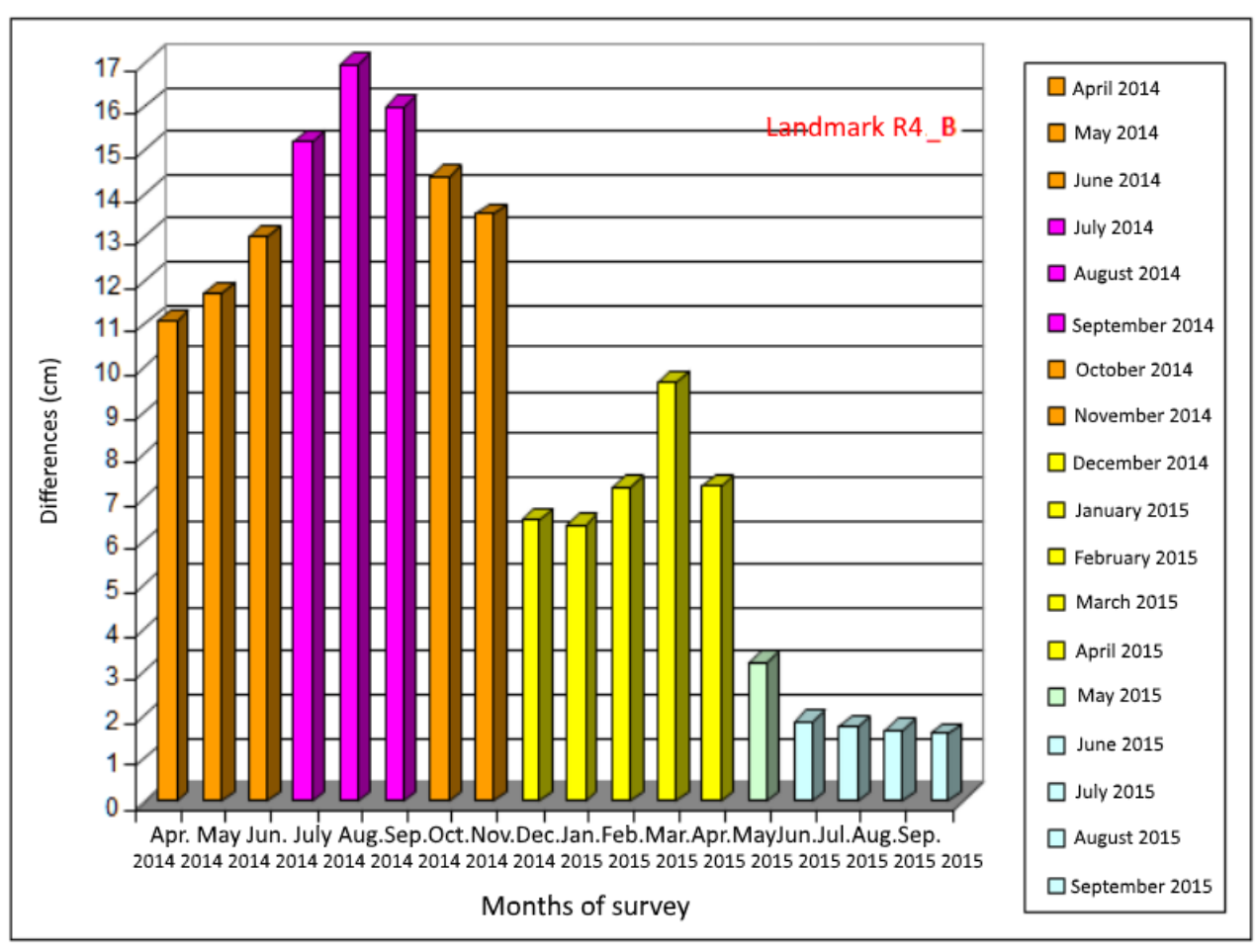

Fig. 5. Evolution of the subsidences on the landfill - Landmark R4_B 
sciendo

22 Ovidius University Annals Series: Civil Engineering, Year 21, 2019

Table 3: Readings on the topographical landmark R11_B on the Bârlad landfill

\begin{tabular}{|c|c|c|}
\hline \multirow{2}{*}{ Signal name } & \multicolumn{2}{|c|}{$\mathbf{\text { R0.00 } \mathbf { ~ m } ( \text { reference Z } )}$} \\
\hline Date & Signal reading & Differences (cm) \\
\hline April 2014 & 77.12 & 12.88 \\
\hline May 2014 & 76.31 & 13.69 \\
\hline June 2014 & 72.42 & 17.58 \\
\hline July 2014 & 73.79 & 16.21 \\
\hline August 2014 & 72.80 & 17.2 \\
\hline September 2014 & 74.65 & 15.35 \\
\hline October 2014 & 76.26 & 13.74 \\
\hline November 2014 & 76.11 & 13.89 \\
\hline December 2014 & 80.75 & 9.25 \\
\hline January 2015 & 81.33 & 8.67 \\
\hline February 2015 & 80.15 & 9.85 \\
\hline March 2015 & 83.42 & 6.58 \\
\hline April 2015 & 82.75 & 7.25 \\
\hline May 2015 & 83.79 & 6.21 \\
\hline June 2015 & 85.35 & 4.65 \\
\hline July 2015 & 86.16 & 3.84 \\
\hline August 2015 & 87.56 & 2.44 \\
\hline September 2015 & 86.98 & 3.02 \\
\hline
\end{tabular}

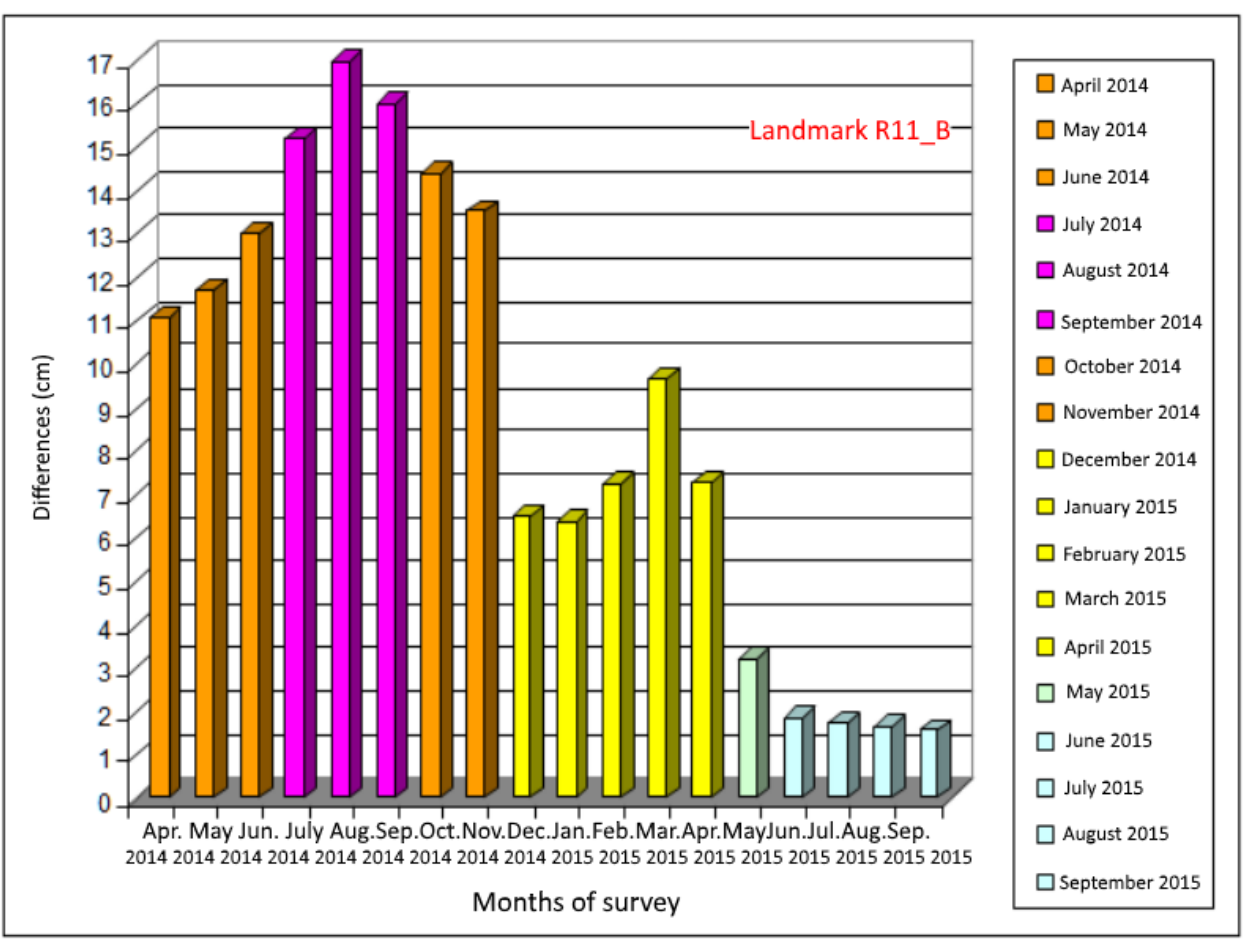

Fig. 6. Evolution of subsidences on the Bârlad landfill - Landmark R11_B 


\subsection{Analysis and interpretation of data}

The adopted model is based on measurements made in the original place. It allows for taking into consideration the heterogeneousness of waste materials without knowing their characteristics. The measurements must be made at a constant time interval $(\Delta t)$. The height of the waste column and the history of filling are not known (useful for applying these methods).

The mathematical model based on Terzaghi's consolidation theory in which an analogy is made between waste behavior and the behavior of a compressible soil. Asaoka developed a method starting from Terzaghi's consolidation theory. This model allows for the determination of the subsidence final amplitude of a waste collection, its consolidation duration and its evolution over time.

Table 4. Values of the internal stability coefficient $\beta$ calculated according to

Terzaghi's theory by the Asaoka method ( $\mathrm{C}++$ simulated numerical method)

\begin{tabular}{|c|c|c|c|c|}
\hline No & Month of measurement & $\begin{array}{c}\text { Bârlad } \\
\text { landfill }\end{array}$ & $\begin{array}{c}\text { Huşi } \\
\text { landfill }\end{array}$ & $\begin{array}{c}\text { Negreşti } \\
\text { landfill }\end{array}$ \\
\hline 1. & April 2014 & No data from the previous month \\
\hline 2. & May 2014 & 2.15 & 2.08 & 1.10 \\
\hline 3. & June 2014 & 2.58 & 2.19 & 1.15 \\
\hline 4. & July 2014 & 2.47 & 2.23 & 1.17 \\
\hline 5. & August 2014 & 2.33 & 2.26 & 1.24 \\
\hline 6. & September 2014 & 2.18 & 1.25 \\
\hline 7. & October 2014 & 2.56 & 2.08 & 1.18 \\
\hline 8. & November 2014 & 2.17 & 2.17 & 1.11 \\
\hline 9. & December 2014 & 1.95 & 1.97 & 1.04 \\
\hline 10. & January 2015 & 1.95 & 1.90 & 1.04 \\
\hline 11. & February 2015 & 2.17 & 1.92 & 1.08 \\
\hline 12. & March 2015 & 1.95 & 1.13 \\
\hline 13. & April 2015 & 2.11 & 2.31 & 1.17 \\
\hline 14. & May 2015 & 2.74 & 2.26 & 1.57 \\
\hline 15. & June 2015 & 2.97 & 2.31 & 1.47 \\
\hline 16. & July 2015 & 2.26 & 2.09 & 1.03 \\
\hline 17. & August 2015 & 1.52 & 1.13 & 0.98 \\
\hline 18. & September 2015 & 1.18 & 1.17 & 0.98 \\
\hline
\end{tabular}

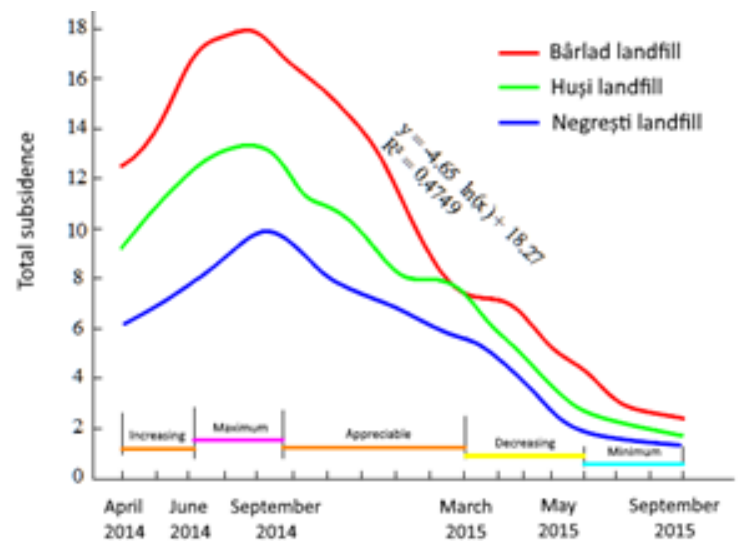

Fig. 7. Evolution of subsidences on the three studied landfills

Figure 7 shows the maximum amplitude between June and October 2014, and the logarithmic equation of the curve shows that the secondary pressure is noticeable until June 
2015. According to Terzaghi's theory, the body of waste can be considered "without mechanical activity," when within 3 consecutive months the difference in $\Delta \mathrm{S}$ of the subsidences is less than $0.5-0.7 \mathrm{~cm}$. This aspect is noticed in the studied landfills from July 2015 to September 2015, when measurements made on ground come to an end.

The $\beta$ coefficient of internal stability according to Terzaghi's theory, calculated according to Terzaghi's theory by the Asaoka method (numerical method simulated in $\mathrm{C}++$ programming) varies between 1.17 ... 2.97 for the Bârlad and Huşi landfills. The maximum value results from the calculation in June 2015. Since August 2015, the $\beta$ coefficient has started to decline, reaching $1.17 \ldots 1.18$ for the end of September, which shows that internal stability is below the critical threshold of 1.50 .

\section{CONCLUSIONS}

During the working stages and as a result of the visits paid on the ground, it was observed that the waste found within the area of the landfills went through an advanced state of decomposition, because more than 7 years passed since the date when their storage was suspended. We hereby notify you that Order 757/2004, [2] provides that the duration of the great subsidences is of 3 to 5 years after the cessation of storage. In addition, it was noticed a lack of gas emissions resulting from biodegradable waste decomposition.

Following the analysis and interpretation of the data, the conclusions are:

- The maximum subsidences took place between June 2014 and November 2014.

- Considerable subsidences took place between November 2014 and June 2015 and the major subsidences are observed after snow melting and infiltration of water from rain.

- On the landfill body there appeared differentiated and uneven subsidencies, therefore final profilation could not be performed.

- Because of the uneven and differentiated subsidences on the landfill body, it was not recommended to proceed to the next stage of installing the gas wells, as the possible subsidences/ displacements from the landfill body could lead to the cutting or displacement of this installation.

- Because of the uneven and differentiated subsidences on the landfill body, the integrity of the bentonite geocomposite may be affected; this being affected in case of uneven compressions greater than $10 \mathrm{~cm} / \mathrm{ml}$ (maximum elongation).

- Due to uneven and differentiated subsidences on the landfill, drainage / drainage channels may appear at the surface of the landfill site body, endangering stability.

\section{REFERENCES}

[1] Neculau Claudia, Biali Gabriela (2017), Mathematical models used for modeling compaction processes resulting from soil mechanics. Bulletin of the Polytechnic Institute of Iaşi, Volume 63 (67), Number 1-2 /2017, p. 9-25, Editura Politehnium, ISSN 1224-3892, e-ISSN $2601-2359$.

[2] ***, Ordinul 757/2004 - Normativul tehnic privind depozitarea deșeurilor.

[3] ***, Acordul de Mediu nr. 12/12.11.2009, revizuit 28.12.2010, Vaslui.

\section{Note:}

Biali Gabriela - "Gheorghe Asachi”" Technical University of Iasi, Bd. D. Mangeron, Nr.65, Iasi, Romania (corresponding author to provide phone: +40-745-295046; e-mail: gbiali@yahoo.com). Schneider Petra - University of Applied Sciences Magdeburg, Stendal, Germany 